\title{
Bacteriophage Therapy: An Alternative to Antibiotics-An Experimental Study in Mice
}

\author{
${ }^{1}$ Laboratory of Bacteriophage Therapy and Functional Genomics, \\ Institute of Medical Sciences, Banaras Hindu University, Varanasi, \\ Uttar Pradesh, India \\ 2Department of Microbiology, Viral Research and Diagnostic \\ Laboratory, Institute of Medical Sciences, Banaras Hindu \\ University, Varanasi, Uttar Pradesh, India
}

Gopal Nath ${ }^{1,2}$ Ram Janam Rajesh Kumar $^{2}$ Mayank Gangwar

\begin{abstract}
Address for correspondence Gopal Nath, MD, PhD, FAMS, Department of Microbiology, Viral Research and Diagnostic Laboratory, Institute of Medical Sciences, Banaras Hindu University, Varanasi, Uttar Pradesh 221005, India (e-mail: gopalnath@gmail.com).
\end{abstract}

\begin{abstract}
Keywords

- Pseudomonas aeruginosa

- bacteriophage cocktail

- multidrug resistant

- mouse model

The present study was planned to evaluate the efficacy of Pseudomonas aeruginosa specific phages in immunocompromised septicemia animal model as an alternative to antibiotics. Five different sets of experiments were performed: prophylactic administration of phage cocktail ( 3 lytic and unique) before and simultaneous with bacterial challenge; and therapeutic, that is, administration of phage cocktail 6,12 , and 24 hours after the bacterial challenge. No mortality was observed when simultaneous and late administration of phages was done with respect to the bacterial challenge. Contrary to this, administration of phage cocktail $100 \mu \mathrm{L}\left(10^{12} \mathrm{PFU} / \mathrm{mL}\right)$ of volume after 6 hours of the infection resulted in a mortality rate of $60 \%$. However, no mortality could be observed with reduced dose of cocktail, that is, $10^{8}, 10^{9}$, and $10^{10} \mathrm{PFU}$ administered 6 hours after bacterial challenge. Phage therapy in acute infections initiated with very small dosage under strict supervision may give better results. However, further studies to determine the quantity and frequency of dosage of phage cocktail for septicemia of various durations is strongly indicated.
\end{abstract}

\section{Introduction}

Pseudomonas aeruginosa is a metabolically least demanding gram-negative bacterium that can cause a wide range of opportunistic infections. Individuals with open wounds (burn and trauma), cancer, immunocompromised cystic fibrosis, and septicemia are particularly susceptible to P. aeruginosa infections. ${ }^{1-3}$ Environmental signals during infection cause several genotypic and phenotypic changes enabling $P$. aeruginosa to survive in the form of planktonic cells, colonies, or biofilms. ${ }^{4}$ The increasing frequency of multidrug-resistant strains is particularly concerning as treatment options are severely limited in the absence of effective antibiotics. ${ }^{5,6}$ The problem has reached such a dimension that, at global level, United Nations General Assembly was called in New York in September 2016 to decide the plan for fighting antimicrobial resistance together. This was only the fourth time in the history of the UN that a health topic was discussed at the General Assembly. Other three were HIV, noncommunicable diseases, and Ebola. The delegates and heads of the nations addressed the seriousness and scope of the situation and agreed on sustainable, multisector approaches to address the issue of antimicrobial resistance. The different alternatives suggested are; newer antibacterial molecules, antibacterial peptides, bacteriocins, probiotics, prebiotics, and bacteriophage therapy. Even if a given antibiotic molecule is effective in vitro against the infecting strain, it may fail in vivo because of biofilm formation leading to poor permeation of antibiotics at the infection site. In case of $P$. aeruginosa, it has been observed that in biofilm profile, it may resist biocides up to 100 times greater than the planktonic or free swimming cells. ${ }^{7}$ Rigorous research activities are going on to develop alternatives toward the treatment of infections caused by $P$. aeruginosa. Ironically, active immunization against $P$. aeruginosa in immunocompromised patients has got no relevance. ${ }^{8}$ Of these, the phage therapy 
has emerged as one of most promising alternative to overcome the problem of bacterial resistance. ${ }^{9}$ The capacity of phages through production of highly specific enzymes like polysaccharide depolymerases or alginate lyases to eradicate bacterial biofilms is an important aspect toward their successful implementation in in vivo treatments. Phage cocktails have been applied as alternative or as supportive treatments simultaneously with antibiotics for $P$. aeruginosa eradication causing various infections, such as purulent wounds, septicemia, urinary tract, or lung infections. Many of the previous studies have given conflicting results due to several confounding factors. ${ }^{9-17}$ However, the commercialization of the phage therapy is still far away due to lack of convincing preclinical and clinical trials. Hence, prior to translation of phage therapy into clinical settings, vigorous experimental authentications with extensive in vitro and in vivo studies are needed. The present study, therefore, was planned to see the efficacy of $P$. aeruginosa specific bacteriophage cocktail in septicemia in burn induced immunocompromised mouse model in different experimental settings.

\section{Materials and Methods}

\section{Bacterial Strains and Their Identification}

$P$. aeruginosa isolates were isolated from clinical specimens (pus, blood, urine, cerebrospinal fluid [CSF], wound swabs, etc.) collected from the patients admitted to intensive care unit of a tertiary level university hospital of Banaras Hindu University on Pseudomonas selective media (cetrimide agar). The strains were identified by the methods already described in standard text. The study period extended from December 2012 to July 2014.

All the clinical isolates were identified as $P$. aeruginosa by using standard biochemical and molecular methods. Further study was conducted only on P. aeruginosa confirmed isolates. Antimicrobial susceptibility test of $P$. aeruginosa was done by the standard Bauer-Kirby disc diffusion method. The size of inhibition zones were recorded and interpreted according to the Clinical and Laboratory Standards Institute (CLSI) breakpoint guideline 2012. All the P. aeruginosa strains were tested for their susceptibility to gentamicin (GEN, $10 \mu \mathrm{g}$ ), amikacin (AK, $30 \mu \mathrm{g})$, netilmicin-sulfate (NET, $30 \mu \mathrm{g})$, carbenicillin (CB, $100 \mu \mathrm{g}$ ), piperacillin/tazabactam (PTZ, 100/10 $\mu \mathrm{g}$ ), ceftriaxone (CTR, $30 \mu \mathrm{g})$, ceftazidime (CAZ, $30 \mu \mathrm{g})$, cefepime (CPM, $30 \mu \mathrm{g}$ ), imipenem (IPM, $10 \mu \mathrm{g}$ ), meropenem (MRP, $10 \mu \mathrm{g}$ ), ertapenem (ETP, $10 \mu \mathrm{g}$ ), ciprofloxacin(CIP, $5 \mu \mathrm{g}$ ), levofloxacin (LE, $5 \mu \mathrm{g}$ ), ofloxacin (OF, $5 \mu \mathrm{g}$ ), cotrimoxazole (COT, $25 \mu \mathrm{g}$ ), polymyxin- $\mathrm{B}$ ( $\mathrm{PB}, 300 \mathrm{unit}$ ), chloramphenicol (C, $30 \mu \mathrm{g})$, colistin sodium methanesulfonate $(\mathrm{Cl}, 25 \mu \mathrm{g})$, and azithromycin (AZM, $15 \mu \mathrm{g}$ ).

\section{Phage Isolation and Purification}

Isolation of bacteriophages was done from different water sources (river, ponds, and sewer) by using double agar overlay method with slight modification as described earlier. ${ }^{17}$ In brief, for isolation of bacteriophages, the P. aeruginosa was plated as lawn culture $\left(10^{8} \mathrm{CFU} / \mathrm{mL}\right)$ on Mueller-Hinton agar (MHA). Water specimens from different water bodies were treated with $1 \%$ chloroform $(\mathrm{v} / \mathrm{v})$ for 20 minutes and centrifuged for 15 minutes at $10,778 \times g$. The supernatant in the volume of $1 \mathrm{~mL}$ was flooded on the 5-hour old lawn culture growth (log phage) of the P. aeruginosa (isolated strains from different hosts) on $90-\mathrm{mm}$ nutrient agar plate and incubated overnight at $37^{\circ} \mathrm{C}$. Next day the lawn was washed with $3 \mathrm{~mL} \mathrm{TMG}$ (Tris- $\mathrm{HCl}$, magnesium sulfate, and gelatin $\mathrm{pH}$ 7.4) buffer and centrifuged at $10,778 \times g$ for 15 minutes. The supernatant $(1 \mathrm{~mL})$ was transferred to a $1.5 \mathrm{~mL}$ microcentrifuge tube. One drop of chloroform was added and mixed well by vortexing or by inversion for 15 minutes. Centrifugation was done at $10,778 \times g$ for 10 minutes. The lawn culture in log phase of the host was again prepared and the supernatant collected as mentioned above was inoculated in the volume of $100 \mu \mathrm{L}$ at 10 to 12 places to screen for lysis. The surface with clear plaque was cut and collected in $1 \mathrm{~mL}$ of the TMG buffer and propagated further and plaque counting was done by soft agar overlay method. ${ }^{18}$ The single isolated plaque was picked up for further processing. The number of phage particle was increased by soft agar overlay method. After bulk production, the bacteria were killed by $1 \%$ chloroform and centrifuged. The clear supernatant was preserved at $4^{\circ} \mathrm{C}$ for further use. For purification (toxin free) and concentration of phages the harvested fluid was subjected to membrane dialysis against polyethylene glycol (PEG 6,000; $20 \%$ in $2.5 \mathrm{M} \mathrm{NaCl}$ ) for overnight and then washed with PBS (phosphate buffer saline) at $4^{\circ} \mathrm{C}$. This process was repeated twice at $4^{\circ} \mathrm{C}$.

\section{Assessment of Anti-P. aeruginosa Activity of Bacteriophages}

\section{Bacteriophage Host Range Determination}

All the 35 isolated phages were subjected to the assessment of their antibacterial activity on a total of 100 clinical isolates of $P$. aeruginosa. The lawn culture of $P$. aeruginosa $\left(10^{8} \mathrm{CFU} / \mathrm{mL}\right)$ was made on MHA. Each of the phages having concentration of $10^{9}$ plaque forming unit (PFU)/mL was spotted on the plate in the volume of $10 \mu \mathrm{L}$. The plates were observed for the clear zone after overnight incubation at $37^{\circ} \mathrm{C}$. Each phage was tested against all the bacterial strains in duplicate in independent experiments.

\section{Isolation of Bacteriophage DNA}

Isolation of phage DNA was performed with phenol/chloroform and ethanol precipitation method. Briefly, purified phage particles $\left(10^{10}-10^{12} \mathrm{PFU} / \mathrm{mL}\right)$ were treated with $1 \mu \mathrm{g}$ of DNase I and RNase A (Bangalore Genei, Bangalore, India) at $37^{\circ} \mathrm{C}$ for 30 minutes. To the mixture, proteinase- $\mathrm{K}$ (Bangalore Genei, Bangalore, India), and SDS were added at a final concentration of $0.05 \mathrm{mg} / \mathrm{mL}$ and $0.5 \%$ respectively and incubated at $56^{\circ} \mathrm{C}$. After 1 hour of incubation, an equal volume of phenol:chloroform was added to remove proteinaceous material. The extraction was repeated thrice with phenol-chloroform-isoamyl alcohol (25:24:1). The nucleic acid was precipitated with chilled ethanol and suspended in $20 \mu \mathrm{L}$ of TE buffer ( $10 \mathrm{mM}$ Tris- $\mathrm{HCl}, \mathrm{pH}=7.0$; $1.0 \mathrm{mM}$ EDTA, $\mathrm{pH}=7.0$ ) according to standard procedure. ${ }^{19}$ 


\section{Genotyping of Bacteriophages by ERIC-PCR}

All the bacteriophages were subjected to genotyping by ERIC-PCR (used on the principle of RAPD). This test was used to genotype the phages to see whether they were genotypically similar or different. This test enabled us to pick up the phages which were not only different in antibacterial activity wise but different genotypically also. The primer sequences used for ERIC and PCR conditions are given in - Table 1. The ERIC primers were used like RAPD with $49^{\circ} \mathrm{C}$ as annealing temperature rather than $61^{\circ} \mathrm{C} .{ }^{20} \mathrm{PCR}$ was performed in $25 \mu \mathrm{L}$ volume using $10 \mathrm{ng}$ of genomic DNA, $1 \mathrm{U}$ of Taq polymerase (Bangalore Genie, India), and $15 \mathrm{pmol}$ of each primer (Bangalore Genie), $200 \mathrm{mmol} / \mathrm{L}$ (each) deoxynucleotide triphosphate (Bangalore Genie, India), and $2 \mathrm{mmol} / \mathrm{L} \mathrm{MgCl}_{2}$ in standard PCR buffer. Amplification reactions were performed in a thermal cycler (Biometra, Goettingen, Germany).

\section{Preparation of Dendrogram}

The gel images were analyzed under ultraviolet light using a gel documentation system (BioRad, Universal Hood II, United States). The size of DNA bands were estimated according to molecular weight markers. Cluster analysis of all the 22 bacteriophages was done on the basis of the fingerprints generated. Based on the banding patterns obtained from ERIC-PCR, dendrogram was constructed. For each phage a haplotype matrix or a binary table was manufactured by linearly composing lysis (1) and no lysis (0), data derived from gel analysis of ERIC-PCR. The resulting similarity matrix was used as the input data for cluster analysis by NTSYS pc2.0 program of UPGMA. ${ }^{21}$

\section{Phage Cocktail Preparation}

The three most potent bacteriophages $\phi$ psbhu-1, $\phi$ psbhu-15, and $\phi p s b h u-17$ were purified and made toxin free with membrane dialysis (dialysis membrane-135, HiMedia Laboratories Pvt. Ltd. Mumbai, India). A phage cocktail containing equal concentration and volume of above three phages were tittered at $1 \times 10^{12} \mathrm{PFU} / \mathrm{mL}$. These phages were different from each other genotypically based on ERIC PCR and also activity wise on 100 indicator strains of $P$. aeruginosa.

\section{Animal Model Studies}

The study protocol was approved by Institute Animal Ethics Committee of Banaras Hindu University.

\section{Safety of Bacteriophage Cocktail}

A group of 10 adult Swiss albino mice approximately 6 to 8 weeks old were taken and $100 \mu \mathrm{L}$ intraperitoneal $(\mathrm{I} / \mathrm{P})$ injection of phage cocktail consisting of $\phi p s b h u-1$, ppsbhu-15, and $\phi$ psbhu-17 at the concentration of approximately $2 \times 10^{12} \mathrm{PFU} / \mathrm{mL}$ was given to them without anesthesia and burn injury. These mice were observed for 1 month. None of the mice was found sick or dead.

\section{Determination of LD100}

A group of 10 adult Swiss albino mice approximately 6 to 8 weeks old on antibiotic free diet were taken and anaesthetized with help of optimum dose of ether. Care was taken to avoid deep anesthesia. Mice were placed into a template with an opening of $4.5 \mathrm{~cm}$ by $1.8 \mathrm{~cm}$ to expose their shaved backs. Third-degree thermal injury to the skin was induced by the exposed back area to the coin template dipped into $90^{\circ} \mathrm{C}$ water for 10 seconds. About $0.8 \mathrm{~mL}$ of ringer's lactate solution was administered immediately following the burn. The mice were challenged by intraperitoneal injection of $100 \mu \mathrm{L}$ (inoculums containing $1 \times 10^{6}$ to $1 \times 10^{9} \mathrm{CFU} / \mathrm{mL}$ ) the P. aeruginosa strain (PS BHU-17), was resistant to gentamicin, netilmicin, amikacin ceftazidime, meropenem, ciprofloxacin, and piperacillin/tazobactam but sensitive to tobramycin, was isolated from a burn wound of a patient. The mice were kept under observation in an ambient environment. It was observed that all the mice died between 36 and 72 hours of the infection. Liver, spleen, heart, and peritoneum fluids of dead mice were collected at postmortem examinations. Individual organs were weighted and suspended in $2 \mathrm{~mL}$ of PBS. They were then homogenized using Wheaton overhead stirrers. The homogenate was plated on MHA plate to see the bacterial growth.

\section{Assessment of Clinical Efficacy of the Phage Cocktail}

We used phage cocktail as prophylactic, as well as therapeutic purposes. The mice experiments were set up in following groups and each group contained five mice.

\section{Group A}

Bacteriophage cocktail was given at constant dose, that is, in the volume of $100 \mu \mathrm{L}$ containing $10^{12} \mathrm{PFU} / \mathrm{mL}$. Further, the bacterial challenge of $100 \mu \mathrm{L}$ of $P$. aeruginosa in the concentration of $1 \times 10^{9} \mathrm{CFU} / \mathrm{mL}$ was given in all the settings of this section of the study.

A.1) Simultaneous administration of bacteriophage and P. aeruginosa challenge:

The above mentioned dosage of bacterial challenge and bacteriophage cocktail was given in the different flanks through intraperitoneal route.

A.2) Bacteriophage cocktail 6 hours later to bacterial challenge:

The bacterial challenge was given 6 hours later to the initial prophylactic protection by the dose mentioned above. The mice were observed for 96 hours.

A.3) Bacteriophage cocktail 6 hours before bacterial challenge:

Table 1 Primer set, annealing temperature, amplicon size, and references of the protocol used in the study

\begin{tabular}{|l|l|l|l|l|}
\hline Gene targets & Oligos & $\begin{array}{l}\text { Annealing } \\
\text { Temperature }\end{array}$ & $\begin{array}{l}\text { Amplicon } \\
\text { size (bp) }\end{array}$ & Reference \\
\hline ERIC-PCR & $\begin{array}{l}\text { F-5'-ATGTAAGCTCCTGGGGATTCAC-3' } \\
\text { R-5'-AAGTAAGTGACTGGGGTGAGCG-3' }\end{array}$ & $49^{\circ} \mathrm{C}$ & Multiple & 20 \\
\hline
\end{tabular}


Initially the bacterial challenge was given and 6 hours later the bacteriophage cocktail was given in the different flank of abdomen.

A.4) Bacteriophage cocktail 12 hours after bacterial challenge:

Initially the bacterial challenge was given and 12 hours later the bacteriophage cocktail was given in the different flank of abdomen.

A.5) Bacteriophage cocktail 24 hours after bacterial challenge:

Initially the bacteria challenge was given and 24 hours later the bacteriophage cocktail was given in the different flank of abdomen.

\section{Group B}

Assessment of Phage Efficacy after Decreasing the Volume of Phage Cocktail

Bacteriophage cocktail 6 hours after bacterial challenge of 20 , 40 , and $60 \mu \mathrm{L}$ of approximately $2 \times 10^{12} \mathrm{PFU} / \mathrm{mL}$ of the three different dosages were given to three different groups (five mice in each group).

Grading of diseases: The grading of the disease was done as follows: grade-I, normal when there was no obvious change seen in the experimental animals; grade II was given to those mice who had slight illness, lethargy and ruffled fur; grade-III scoring was given to the mice having moderate illness, severe lethargy, ruffled fur, and hunched back; grade IV to those having severe illness with above sign, exudative accumulation around eyes; and grade $\mathrm{V}$ to those who died at the point of examination.

\section{Statistical Analysis}

Data were expressed as means \pm standard deviation (SD) of mean and statistical analysis was performed with Wilcoxon's signed-ranked test using student's t-test for calculations of mean and SD. Difference with $p \leq 0.05$ was considered as statistically significant.

\section{Results}

\section{Safety of Bacteriophage Cocktail}

When the phage cocktail was given at the concentration of approximately $2 \times 10^{12} \mathrm{PFU} / \mathrm{mL}$, none of the mice was found sick or dead when observed for 1 month.

\section{Determination of LD100}

The challenge bacterial strain could give 100\% mortality in 36 to 48 hours at the dose of $100 \mu \mathrm{L} 1 \times 10^{9} \mathrm{CFU} / \mathrm{mL}$.

\section{Prophylactic Treatment}

Simultaneous Administration of Bacteria and Phage Cocktail

No mortality occurred in any mice. The score of morbidity is given in - Table 2 .

Bacteriophage Cocktail 6 Hours before Bacterial Challenge Result of prophylactic study states that only two (20\%) out of 10 treated mice died after 12 hours. However, rest of eight mice (80\%) survived and recovered to normal healthy level after 72 hours of the infection.

\section{Administration of $P$. aeruginosa 6 Hours before Bacteriophage Cocktail}

In our result, death of six mice out of 10 mice was observed within 24 hours of infection and remaining four mice recovered to normal healthy after 72 hours of infection.

\section{Administration of $P$. aeruginosa 12 Hours before \\ Bacteriophage Cocktail}

In our result, none of the mice died in this group. Only they remain sick up to 48 hours and after 72 hours they recovered to normal healthy.

\section{Administration of $P$. aeruginosa 24 Hours before} Bacteriophage Cocktail

In our result, none of the mice died in this group. Only they remain sick up to 48 hours and after 72 hours they recovered to normal healthy.

\section{Concentration Dependent Phage Cocktail}

We observed that none of the mice died in these three groups as described above. However, the mice of given $60 \mu \mathrm{L}$ of phage cocktail was observed more sick at 24 hours than the rest of two groups. Further recovery was very slow in the group received $20 \mu \mathrm{L}$ of phage cocktail ( - Fig. 1).

\section{Assessment of Phage Efficacy after Decreasing Volume} of Phage Cocktail after 6 Hours of Bacterial Challenge

Bacteriophage cocktail 6 hour after bacterial challenge of 20,40 , and $60 \mu \mathrm{L}$ of approximately $2 \times 10^{12} \mathrm{PFU} / \mathrm{mL}$ of the three different dosage were given to three different groups (five in each group) of mice.

\section{Bacteriophage Cocktail Dose having $60 \mu \mathrm{L}$ of Approximately $2 \times 10^{12} \mathrm{PFU} / \mathrm{mL}$}

A total of three out of five mice belonging to this group had increased severity and developed additional sign of exudative accumulation around the eyes. No death was noted. In the rest of the mice severe illness persisted at 72 hours but improved and became normal at 96 hours ( - Fig. 1).

\section{Bacteriophage Cocktail Dose having $40 \mu \mathrm{L}$ of Approximately $2 \times 10^{12} \mathrm{PFU} / \mathrm{mL}$}

This group receiving $40 \mu \mathrm{L}$ of approximately $2 \times 10^{12}$ had severe illness persisting up to 72 hours with the peak at 24 hours. In this group also severe illness continued up to 72 hours. However, all of them became healthy after 96 hours.

\section{Bacteriophage Cocktail Dose having $20 \mu \mathrm{L}$ of Approximately $2 \times 10^{12} \mathrm{PFU} / \mathrm{mL}$}

This group receives $20 \mu \mathrm{L}$ of approximately $2 \times 10^{12}$ of the cocktail. All the five mice had all the signs of severe infection at 24 hours after the start of the therapy. The sickness persisted up to 72 hours with complete recovery at 96 hours (-Fig. 2 ) 
Table 2 The effect of bacteriophage therapy in different experimental groups along with criterion for scoring

\begin{tabular}{|c|c|c|c|c|c|}
\hline \multicolumn{6}{|c|}{ Observation made after intervention with bacteriophages at $12,24,48,72$, and 96 hours } \\
\hline $\begin{array}{l}\text { A. Bacteriophage cocktail } \\
\text { given in the volume of } \\
100 \mu \text { containing } 10^{11} \\
\text { PFU ( } 10 \text { mice in each } \\
\text { group) }\end{array}$ & 12 & 24 & 48 & 72 & 96 \\
\hline $\begin{array}{l}\text { I) Simultaneous adminis- } \\
\text { tration of bacteriophage } \\
\text { and Pseudomonas aerugi- } \\
\text { nosa challenge }\end{array}$ & $\begin{array}{l}2^{\mathrm{a}}+2+3+3+3 \\
+2+3+2+2+3 \\
(2.5)\end{array}$ & $\begin{array}{l}3+3+3+3+3+3 \\
+3+3+3+3 \\
(3.0)\end{array}$ & $\begin{array}{l}2+3+3+3+2+2 \\
+3+3+2+3 \\
(2.6)\end{array}$ & $\begin{array}{l}1+1+1+1+1+1+ \\
1+1+1+2 \\
(1.1)\end{array}$ & $\begin{array}{l}1+1+1+1+1+1 \\
+1+1+1+1 \\
(1.0)\end{array}$ \\
\hline $\begin{array}{l}\text { II) Bacteriophage cocktail } 6 \\
\text { h before bacterial challenge }\end{array}$ & $\begin{array}{l}2+2+3+3+3+3 \\
+3+3+3+3 \\
(2.8)\end{array}$ & $\begin{array}{l}3+3+5+3+3+5 \\
+3+3+3+3 \\
(3.4)\end{array}$ & $\begin{array}{l}2+2+5+3+3+5 \\
+2+3+3+3 \\
(3.2)\end{array}$ & $\begin{array}{l}2+2+5+2+2+5+2 \\
+2+2+2 \\
(\mathbf{2} .6)\end{array}$ & $\begin{array}{l}1+1+5+1+1+5 \\
+1+1+1+1 \\
(1.8)\end{array}$ \\
\hline $\begin{array}{l}\text { III) Bacteriophage cocktail } 6 \\
\text { h after bacterial challenge }\end{array}$ & $\begin{array}{l}5+5+3+3+5+5 \\
+3+2+5+3 \\
(3.9)\end{array}$ & $\begin{array}{l}5+5+3+3+5+5 \\
+5+3+5+3 \\
(4.2)\end{array}$ & $\begin{array}{l}5+5+3+3+5+5+ \\
5+3+5+3 \\
\mathbf{( 4 . 2 )}\end{array}$ & $\begin{array}{l}5+5+2+1+5+5 \\
+5++5+1 \\
(3.5)\end{array}$ & $\begin{array}{l}5+5+1+1+5+5 \\
+5++5+1 \\
(3.4)\end{array}$ \\
\hline $\begin{array}{l}\text { IV) Bacteriophage cock- } \\
\text { tail } 12 \mathrm{~h} \text { after bacterial } \\
\text { challenge }\end{array}$ & $\begin{array}{l}2+3+3+3+3+3 \\
+3+2+3+3 \\
(2.8)\end{array}$ & $\begin{array}{l}3+3+3+3+3+3 \\
+3+3+3+3 \\
(3.0)\end{array}$ & $\begin{array}{l}2+3+3+3+3+3 \\
+3+3+3+3 \\
(2.9)\end{array}$ & $\begin{array}{l}1+2+1+1+1+2+1 \\
+2+1+1 \\
(1.3)\end{array}$ & $\begin{array}{l}1+1+1+1+1+1 \\
+1+1+1+1 \\
(1.0)\end{array}$ \\
\hline $\begin{array}{l}\text { V) Bacteriophage cocktail } \\
24 \text { h after bacterial } \\
\text { challenge }\end{array}$ & $\begin{array}{l}2+2+3+3+3+3 \\
+3+2+3+3 \\
(2.7)\end{array}$ & $\begin{array}{l}3+3+3+3+3+3 \\
+3+3++3 \\
(3.0)\end{array}$ & $\begin{array}{l}2+2+3+3+3+3 \\
+2+3+2+2 \\
(2.6)\end{array}$ & $\begin{array}{l}1+2+1+1+1+1+1 \\
+1+1+3 \\
(1.3)\end{array}$ & $\begin{array}{l}1+1+1+1+1+1 \\
+1+1+1+1 \\
(1.0)\end{array}$ \\
\hline \multicolumn{6}{|l|}{$\begin{array}{l}\text { B. Bacteriophage cocktail } \\
\text { given in the volume of } \\
100 \mu l\end{array}$} \\
\hline $\begin{array}{l}\text { IIIA) Bacteriophage } \\
\text { cocktail } 6 \text { h after bacterial } \\
\text { challenge (dose } 1.6 \times 10^{10} \\
\text { PFU) }{ }^{\text {b }}\end{array}$ & $\begin{array}{l}2+3+2+3+3 \\
(2.6)\end{array}$ & $\begin{array}{l}3+3+3+3+3 \\
(3.0)\end{array}$ & $\begin{array}{l}1+1+1+1+1 \\
(\mathbf{1 . 0 )}\end{array}$ & $\begin{array}{l}1+1+1+1+1 \\
(1.0)\end{array}$ & $\begin{array}{l}1+1+1+1+1 \\
(\mathbf{1 . 0 )}\end{array}$ \\
\hline $\begin{array}{l}\text { IIIB) Bacteriophage } \\
\text { cocktail } 6 \text { h after bacterial } \\
\text { challenge (dose } 2.5 \times 10^{9} \\
\text { PFU) }{ }^{\text {b }}\end{array}$ & $\begin{array}{l}2+2+2+2+2 \\
(2.0)\end{array}$ & $\begin{array}{l}2+1+1+2+2 \\
(1.6)\end{array}$ & $\begin{array}{l}1+2+1+2+2 \\
(1.6)\end{array}$ & $\begin{array}{l}1+1+1+1+1 \\
(\mathbf{1 . 0 )}\end{array}$ & $\begin{array}{l}1+1+1+1+1 \\
(\mathbf{1 . 0 )}\end{array}$ \\
\hline $\begin{array}{l}\text { IIIC) Bacteriophage cock- } \\
\text { tail } 24 \text { h after bacterial } \\
\text { challenge (dose } 5 \times 10^{8} \\
\text { PFU) }\end{array}$ & $\begin{array}{l}2+2+2+3+3 \\
(2.4)\end{array}$ & $\begin{array}{l}2+2+3+3+3 \\
(2.6)\end{array}$ & $\begin{array}{l}2+2+3+3+3 \\
(2.6)\end{array}$ & $\begin{array}{l}1+1+2+2+1 \\
(1.4)\end{array}$ & $\begin{array}{l}1+1+1+1+1 \\
(\mathbf{1 . 0})\end{array}$ \\
\hline
\end{tabular}

Note:1-Normal; 2-Slight illness, lethargy, ruffled fur; 3-Moderate illness, severe lethargy, ruffled fur and hunched back; 4-Severe illness with above sign, exudative accumulation around eyes; 5 - Death; Figure in parenthesis shows the average of the signs of all the 5 mice in a particular study group.

a Grading of diseases.

bexperiment done on 5 mice only.

\section{Discussion}

This study was aimed to evaluate the efficacy of bacteriophage cocktail as an alternative antibacterial therapy to deal with the MDR/XDR/PDR strain of $P$. aeruginosa leading to severe morbidity and mortality in clinical settings, especially septicemia and pneumonia. The focus of the study was to evaluate the protective effect when phage therapy is started at different time intervals after setting up the infection and also to have clues regarding dosage of the cocktail.

For the purpose, $P$. aeruginosa isolate resistant to all the available antipseudomonal drugs was picked up. The dose of $100 \mu \mathrm{L}\left(10^{9} \mathrm{CFU} / \mathrm{mL}\right)$ of the bacterium was found to result into $100 \%$ mortality between 24 and 48 hours when injected intraperitoneally. On postmortem examination pure $P$. aeruginosa isolation from all the vital organs established the cause of death due to the bacterium. Further, we prepared the cocktail of the three different and the most virulent bacteriophages and tested them for safety in five healthy mice injecting through IP route. We observed no adverse effect. To assess the efficacy of cocktail at a random concentration $\left(10^{12} \mathrm{PFU} / \mathrm{mL}\right)$ administered at different time points as patient may report to intensive care units at different intervals after ensuing the $P$. aeriginosa septicemia. Five different sets of experiments having 10 mice in each group were performed. The first group received bacteriophage cocktail as prophylactic antibacterial administered simultaneously with the challenge dose of the bacterium considering that infection caused by $P$. aeruginosa may occur soon after inflicting the wound. We found that the severity of disease was minimal resulting into no mortality. This observation indicates that the 


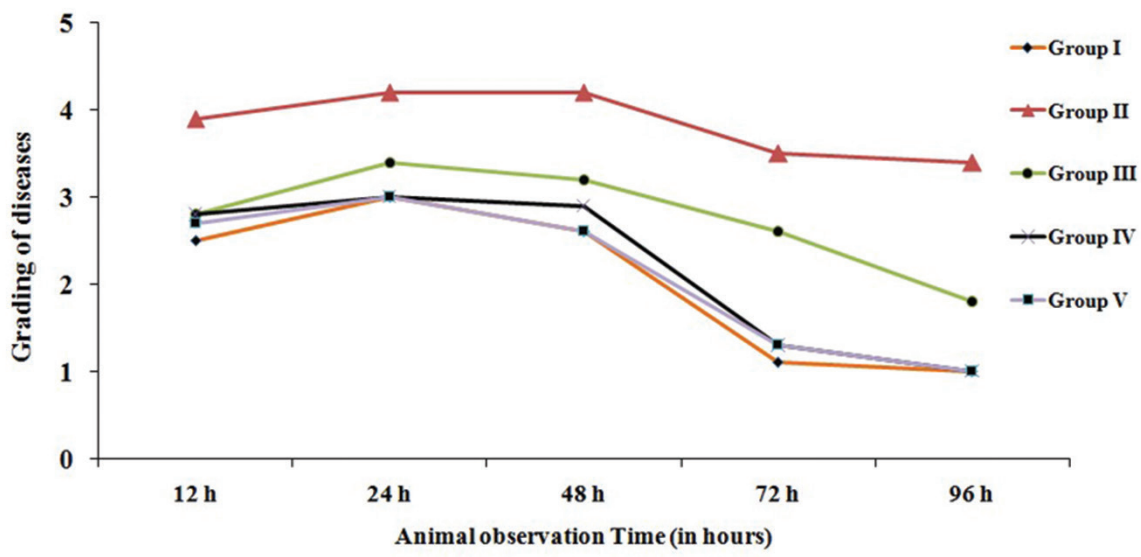

Fig. 1 Effect of pseudomonas aeruginosa and bacteriophage cocktail for clinical grading of diseases based of time of inoculation. Disease grading denoted by numbering 1: normal; 2: slight illness, lethargy, and ruffled fur; 3: moderate illness, severe lethargy, ruffled fur and hunched back; 4: severe illness with above sign, exudative accumulation around eyes; 5: death. Group I: bacteriophage ( $)$ + bacteria simultaneously; group II: pretreatment of $\emptyset 6$ hours before bacterial challenge; group III: $\varnothing 6$ hours later bacterial challenge; group IV: $\emptyset 12$ hours later bacterial challenge; group V: Ø 24 hours later bacterial challenge.

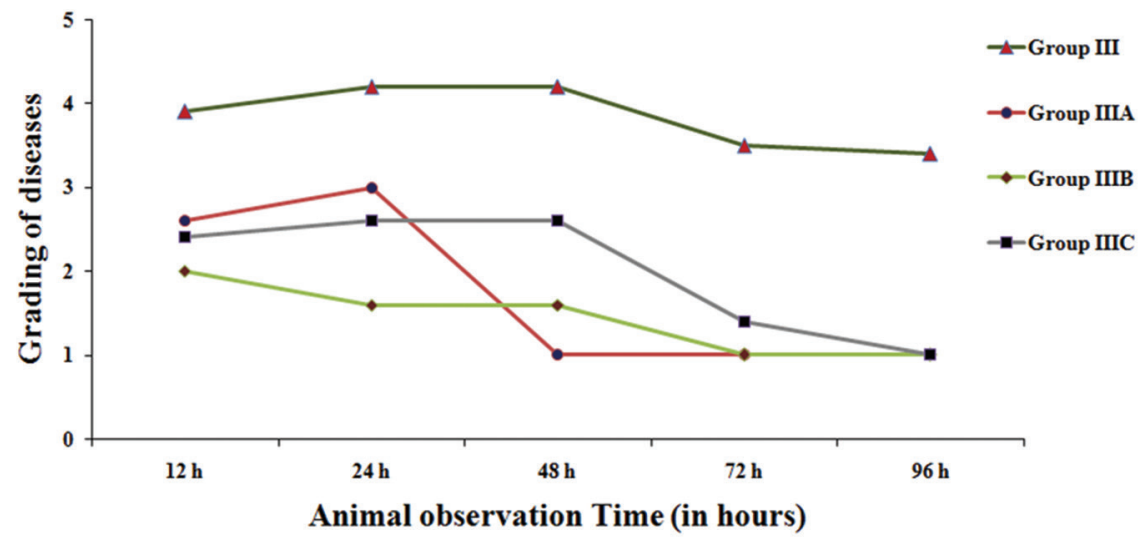

Fig. 2 Effect of pseudomonas aeruginosa at reduced dosage when bacteriophage cocktail was given 6 hours later bacterial challenge for clinical grading of diseases based on the time of inoculation. Disease grading denoted by numbering 1: normal; 2: slight illness, lethargy, and ruffled fur; 3: moderate illness, severe lethargy, ruffled fur and hunched back; 4: severe illness with above sign, exudative accumulation around eyes; 5 : death. Group III: bacteriophage ( $\varnothing$ )

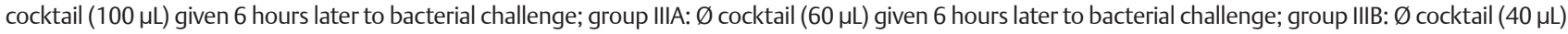
given 6 hours later to bacterial challenge; group IIIC: $\varnothing$ cocktail $(20 \mu \mathrm{L})$ given 6 hours later to bacterial challenge.

P. aeruginosa specific bacteriophage cocktail prevents the death if given in advance before the infection sets in. However, in the second group when the bacterial challenge was given 6 hours before the bacteriophage cocktail, the mortality in the mice was $60 \%$. The third experimental group, the bacteriophage cocktail given 6 hours before the bacterial challenge, led to death of $20 \%$ of the mice. However, when same dose of cocktail was evaluated after 12 and 24 hours of the initiation of the infection process, there was no mortality in both the groups. This might have occurred because of the fact that around 6 hours of the bacterial and phage challenges, the dosage of cocktail and in vivo multiplied $P$. aeruginosa might have reached at the optimal concentration (zone phenomenon) leading to massive lysis causing severe endotoxic shock. While in groups 4 and 5 , the bacteriophages might have been adsorbed on the host bacteria replicating gradually and causing gradual lysis of the bacteria. This assumption made us to reduce the doses of cocktail in volume to in three different groups of mice to 60,40 , and $20 \mu \mathrm{L}$ in place of $100 \mu \mathrm{L}$ given 6 hours later to bacterial challenge. These decrease dosage delivered phages at the concentration of $1.6 \times 10^{10}, 2.5 \times 10^{9}$, and $5 \times 10^{8} \mathrm{PFU}$ in place of $10^{11} \mathrm{PFU}$. This modification caused no death in the challenged mice 6 hours before the cocktail, although recovery was delayed with the lowest dosage. No death after decrease in dosage might have occurred on the hypothesis that the septicemia being an acute condition, even the small dose of phages replicating in the blood and other tissues where $P$. aeruginosa are actively multiplying and this will slow down the release of the endotoxins and also cure the infection without causing endotoxic shock as liver and kidney are able to tackle the situation. This suggested that the lower dosage of the bacteriophage cocktail may be better with less risk of mortality. It is preliminary study in the area of septicemia and phage therapy and therefore many more questions remain to be answered. Importantly, the question that 
why there was mortality in particular group/s? Is it the sudden bacterial lysis leading massive release of endotoxins and other toxins which is stimulating release and exhaustion of cytokines (tumor necrosis factor [TNF]- $\alpha$, INF- $\beta$ INF- $\gamma$, interleukin [IL]-1, IL-6, etc.) and also causing multiorgan failure? This phenomenon has also been speculated in cases of clinical septicemia where antibiotics acting on cell wall (penicillin, cephalosporins, and carbapenems) are administered as a bolus. ${ }^{22}$ There is another study in healthy rats, where intravenous bolus of $30 \mathrm{mg}$ of ceftazidime per $\mathrm{kg}$ caused to a substantial increase in IL-6 and TNF- $\alpha$ concentrations in serum. ${ }^{23}$ This observation suggests that the increase in parameters of inflammation occurring after initiation of ceftazidime therapy may be a consequence not only of the release of proinflammatory bacterial compounds. Whereas cell wall-active antibacterials can temporarily enhance the liberation of toxic or proinflammatory bacterial compounds, bactericidal antibiotics acting by the inhibition of RNA, or protein synthesis or DNA replication (rifamycins, macrolides, clindamycin, ketolides, and quinolones) delay or even circumvent bacterial lysis. ${ }^{24}$

However, this speculation needs to be confirmed by estimating the counting of bacteria and bacteriophages at different intervals, estimating the endotoxins levels, and proinflammatory cytokines at variable dosage of the bacteriophages. Here, it is pertinent to mention that similar observation has been made with phage therapy in Acinetobacter baumannii immunecompromised mouse septicemia model (unpublished data).

Therefore, it may be suggested to see the levels of bacteremia and monitoring of different cytokines and endotoxin in mouse septicemia model to translate the phage therapy in life threatening $P$. aeruginosa septicemia. The possibility of gradual increase in cocktail dosage or single small dose may be explored for its safety and efficacy also.

\section{Conclusion}

In conclusion, this study strongly supports the use of bacteriophages as therapeutic agents to combat MDR, XDR, and PDR $P$. aeruginosa infections in immunocompromised patients.

\section{Note}

The author was selected for Dr. Pran Nath Chhuttani Oration for the year 2018-2019.

\section{Ethical Approval}

The study protocol was approved by Institute Animal Ethics Committee.

\section{Funding}

We gratefully acknowledge that this research was supported by Department of Biotechnology, Govt. of India, New Delhi, India, in the form of Junior Research Fellowship to Ram Janam.

\section{Conflict of Interest}

None declared.

\section{References}

1 Trautmann M, Lepper PM, Haller M. Ecology of Pseudomonas aeruginosa in the intensive care unit and the evolving role of water outlets as a reservoir of the organism. Am J Infect Control 2005;33(5, Suppl 1):S41-S49

2 Lyczak JB, Cannon CL, Pier GB. Establishment of Pseudomonas aeruginosa infection: lessons from a versatile opportunist. Microbes Infect 2000;2(9):1051-1060

3 Schroeder TH, Reiniger N, Meluleni G, Grout M, Coleman FT, Pier GB. Transgenic cystic fibrosis mice exhibit reduced early clearance of Pseudomonas aeruginosa from the respiratory tract. J Immunol 2001;166(12):7410-7418

4 Bragonzi A, Paroni M, Nonis A, et al. Pseudomonas aeruginosa microevolution during cystic fibrosis lung infection establishes clones with adapted virulence. Am J Respir Crit Care Med 2009;180(2):138-145

5 Breidenstein EBM, de la Fuente-Núñez C, Hancock REW. Pseudomonas aeruginosa: all roads lead to resistance. Trends Microbiol 2011;19(8):419-426

6 Poole K. Pseudomonas aeruginosa: resistance to the max. Front Microbiol 2011;2:65

7 Brooun A, Liu S, Lewis K. A dose-response study of antibiotic resistance in Pseudomonas aeruginosa biofilms. Antimicrob Agents Chemother 2000;44(3):640-646

8 Priebe GP, Goldberg JB. Vaccines for Pseudomonas aeruginosa: a long and winding road. Expert Rev Vaccines 2014;13(4):507-519

9 Pires DP, Vilas Boas D, Sillankorva S, Azeredo J. Phage therapy: a step forward in the treatment of Pseudomonas aeruginosa infections. J Virol 2015;89(15):7449-7456

10 Debarbieux L, Leduc D, Maura D, et al. Bacteriophages can treat and prevent Pseudomonas aeruginosa lung infections. J Infect Dis 2010;201(7):1096-1104

11 Kumari S, Harjai K, Chhibber S. Bacteriophage versus antimicrobial agents for the treatment of murine burn wound infection caused by Klebsiella pneumoniae B5055. J Med Microbiol 2011;60(Pt 2):205-210

12 Khawaldeh A, Morales S, Dillon B, et al. Bacteriophage therapy for refractory Pseudomonas aeruginosa urinary tract infection. J Med Microbiol 2011;60(Pt 11):1697-1700

13 Watanabe R, Matsumoto T, Sano G, et al. Efficacy of bacteriophage therapy against gut-derived sepsis caused by Pseudomonas aeruginosa in mice. Antimicrob Agents Chemother 2007;51(2):446-452

14 Golkar Z, Bagasra O, Pace DG. Bacteriophage therapy: a potential solution for the antibiotic resistance crisis. J Infect Dev Ctries 2014;8(2):129-136

15 Rossitto M, Fiscarelli EV, Rosati P. Challenges and promises for planning future clinical research into bacteriophage therapy against Pseudomonas aeruginosa in cystic fibrosis. An argumentative review. Front Microbiol 2018;9:775

16 McVay CS, Velásquez M, Fralick JA. Phage therapy of Pseudomonas aeruginosa infection in a mouse burn wound model. Antimicrob Agents Chemother 2007;51(6):1934-1938

17 Chan BK, Turner PE, Kim S, Mojibian HR, Elefteriades JA, Narayan D. Phage treatment of an aortic graft infected with Pseudomonas aeruginosa Evol Med Public Health 2018;2018(1):60-66

18 Ellis EL, Delbrück M. The growth of bacteriophages. J Gen Physiol 1939;22(3):365-384

19 Sambrook J, Fritsch EF, Maniatis T, Molecular Cloning: A Laboratory Manual, 2nd ed. New York, NY: Cold Spring Harbor Laboratory Press, Cold Spring Habor

20 Versalovic J, Koeuth T, Lupski JR. Distribution of repetitive DNA sequences in eubacteria and application to fingerprinting of bacterial genomes. Nucleic Acids Res 1991;19(24):6823-6831 
21 Romesburg HC, Cluster Analysis for Researchers. Morrisville, NC: Lulu Press; 2004

22 Nau GJ, Richmond JF, Schlesinger A, Jennings EG, Lander ES, Young RA. Human macrophage activation programs induced by bacterial pathogens. Proc Natl Acad Sci U S A 2002;99(3):1503-1508
23 Horii $\mathrm{T}$, Ichiyama S, Ohta M, Kobayashi M. Relationship between morphological changes and endotoxin release induced by carbapenems in Pseudomonas aeruginosa. J Med Microbiol 1999;48(3):309-315

24 Prins JM. Antibiotic induced release of endotoxin clinical data and human studies. J Endotoxin Res 1996;3(3):269-273 